\title{
Combined effect of exposure to ammonia and hypoxia on the blue shrimp Litopenaeus stylirostris survival and physiological response in relation to molt stage
}

\author{
Chantal Mugnier ${ }^{\mathrm{a},{ }^{*}}$, Etienne Zipper $^{\mathrm{a}}$, Cyrille Goarant ${ }^{\mathrm{a}}$ and Hugues Lemonnier ${ }^{\mathrm{a}}$ \\ a Département Aquaculture en Nouvelle-Calédonie, IFREMER, BP2059, 98846 Nouméa Cedex, New Caledonia \\ *: Corresponding author : C. Mugnier, Tel.: +687-35-25-71; fax: +687-28-78-57, email address: \\ cmugnier@ifremer.fr
}

\begin{abstract}
:
The effect of ambient ammonia, hypoxia and combination of both on survival and the physiological and immunological response of the blue shrimp Litopenaeus stylirostris in relation to molt stage was studied. Shrimp were submitted to $44.0-71.5 \mathrm{mg} \mathrm{l}-1$ total ammonia- $\mathrm{N}$ corresponding to $2.0 \mathrm{mg} \mathrm{l-} 1$ unionized ammonia NH3-N and/or to $1.5 \mathrm{mg} \mathrm{O} 2 \mathrm{l}-1$ ( $4.3 \mathrm{kPa})$ for 24 hours. Survival was recorded and the molt stages of both dead and surviving shrimp determined. Only shrimp in intermolt and premolt stages were sampled for analysis of haemolymph. Haemolymph was assayed for osmoregulatory capacity $(\mathrm{OC})$, magnesium ion $(\mathrm{Mg} 2+)$, calcium ion $(\mathrm{Ca} 2+)$, total proteins, oxyhaemocyanin, lactate, glucose and total haemocyte count (THC).

Low mortalities were recorded for shrimp submitted independently to ammonia or hypoxia. Seventy five percent of dead shrimp were in early post molt (stage A) in ammonia treatment, while hypoxia affected mainly late premolt animals (stage D2). A synergic effect of ammonia and hypoxia combination (A + $\mathrm{O} 2$ treatment) on mortality was observed, affecting nearly exclusively shrimp in late premolt stage $\mathrm{D} 2$.

Analysis of molt stage repartition at the end of the experiment suggests that ammonia treatment may have accelerated molting.

The common physiological response of shrimp to the different treatments was characterized by a reduced $\mathrm{OC}$ and an increase in $\mathrm{Ca} 2+$. Increase in $\mathrm{Mg} 2+$ could not be validated by the statistical analysis, as well as glycaemia variations. Plasmatic lactate level increased and THC decreased in shrimp submitted to hypoxia and the combination of hypoxia and ammonia. Total proteins concentration was reduced in ammonia and $\mathrm{A}+\mathrm{O} 2$ treatments. The effect was more pronounced in late premolt shrimp than in intermolt shrimp. Combination of ammonia and hypoxia led to a physiological response stronger than this observed for ammonia-alone and/or hypoxia-alone treatments, except for oxyhaemocyanin.
\end{abstract}

The effects of each external factor (ammonia, hypoxia) and the combination of both, and internal one (molt stage) are discussed.

Keywords: Ammonia; Haemolymph constituents; Hypoxia; Litopenaeus stylirostris; Molt stage; Penaeid shrimp; Stress; Survival 


\section{Introduction}

Farming of shrimp in semi-intensive culture system may be subjected to environmental variations such as fluctuations of dissolved oxygen, temperature, or accumulation of potentially toxic compounds like ammonia or nitrite (Chien, 1992). Variations of environmental factors are not necessarily independent of each other, and combination of several factors which may be stressful for shrimp could be encountered at the same time in a pond. A consequence of shrimp being stressed may be a decrease in immune defence and an increased susceptibility to pathogens (Le Moullac and Haffner, 2000; Horowitz and Horowitz, 2001).

L. stylirostris is the only species cultivated in New Caledonia. It is the second exported product of the country, but its culture is still a developing industry. Those shrimp benefit an almost virusfree status but are commonly exposed to seasonal mortalities due to vibriosis either during the cold or the warm seasons (Costa et al., 1998; Goarant et al., 2006). Variations in environmental factors seem to have an impact on the mortalities observed (Mermoud et al., 1998).

In New Caledonia, several farms do not use aerators in their ponds. In these conditions, dissolved oxygen may reach critical values, in particular in the last part of grow-out, and shrimp can be exposed to short-term hypoxia (oxygen level from $3 \mathrm{mg} \mathrm{I}^{-1}$ to less than $1 \mathrm{mg} \mathrm{I}^{-1}$ ). It has been shown that short-term decreases of DO concentration can have a negative effect on shrimp osmoregulation (Charmantier et al., 1994; Mugnier and Soyez, 2005) and immune system (Direkbusarakom and Danayadol, 1998; Le Moullac et al., 1998; Le Moullac and Haffner, 2000; Mikulski et al., 2000; Cheng et al., 2002; Burgents et al., 2005; Jiang et al., 2005), and may decrease resistance to diseases (Mikulski et al., 2000; Cheng et al., 2002). Moreover, ammonia- $\mathrm{N}$, which is the principal end-product of nitrogenous compounds, accumulates in ponds and has a deleterious effect on fish and crustaceans (Colt and Armstrong, 1981). Of the ammonia species, the unionised form $\mathrm{NH}_{3}-\mathrm{N}$, which is $\mathrm{pH}-$, temperature- and salinity- dependent, is the most toxic to aquatic life. The effects of ammonia- $\mathrm{N}$ on shrimp or other decapods physiological response or immune resistance are relatively well documented (Wajsbrot et al., 1990; Young-Lai et al., 1991; Chen and Cheng, 1993a; Lin et al., 1993; Schmitt and Uglow, 1997; Racotta and Hernandez-Herrera, 2000; Harris and al., 2001; Cheng and Chen, 2002; Cheng et al., 2003a; Jiang et al., 2004; Liu and Chen, 2004), including for L. stylirostris (Mugnier and Justou, 2004).

The present work aimed at studying the survival and physiological/immunological response of juvenile L. stylirostris to sublethal levels of ammonia $\mathrm{NH}_{3}-\mathrm{N}$ and hypoxia, either separately or combined, in relation to molt stage. Few works have been carried out so far on the short-term effects of the combination of two or more stressors on shrimp, mainly on survival (Allan et al., 1990; Wajsbrot et al., 1990; Chen and Lin, 1992; Chen et al., 1996; Martinez et al., 1998; Parado-Estepa, 1998; Lin and Chen, 2001; Kir et al., 2004; Zhang et al., 2006), and very few on physiological effects (Mugnier and Soyez, 2005; Li et al., 2006). In the present study, survival was considered in relation to the molt stage, and physiological response was studied in intermolt and late premolt shrimp. Premolt animals are more sensitive to stress than intermolt (Wajsbrot et al., 1990) and less resistant to experimental infection with pathogenic Vibrio than intermolt animals (Le Moullac et al., 1997; Cheng et al., 2003b; Liu et al., 2004).

Some physiological indicators measured in the haemolymph and known to be indicative of a stress response were selected for this study. In seawater, penaeid shrimp hypo-osmoregulate, and variation of osmoregulatory capacity $(\mathrm{OC})$, which is the difference in osmotic concentration between haemolymph and surrounding water, was studied. It is a non-specific indicator commonly used for detecting physiological stress, including in L. stylirostris (Lignot et al., 2000). Previous work have shown that total proteins concentration, which can serve as a significant source of metabolic energy for crustaceans (Claybrook 1983), decreased under ammonia stress (Chen et al., 1993, Chen and Cheng 1993a; Mugnier and Justou, 2004). A possible change in oxyhaemocyanin concentration under hypoxia can be expected, as it is the main protein in the haemolymph and is implied in several functions like oxygen transport, enzymatic activities, osmoregulation or buffering (Paul and Pirow, 1997/98).

If anaerobic metabolism occurs, such as under hypoxic conditions, lactate formation and its increase in the haemolymph could be expected (McMahon, 2001; Racotta et al., 2002). At the opposite, a decrease was observed in L. stylirostris submitted to ammonia (Mugnier and Justou, 2004). $\mathrm{Mg}^{2+}$, which plays an important role as a co-factor in enzyme systems and as a modulator of the hemocyanin of crustacean arthropods (Morrit and Spicer, 1993), increases in shrimp haemolymph under different stress conditions (Boglio, 1995; Mugnier and Justou, 2004). 
$\mathrm{Ca}^{2+}$ is implicated in haemolymph buffering, and hypoxia may induce an increase of $\mathrm{Ca}^{2+}$ in haemolymph (Hagerman and Uglow, 1982, McMahon, 2001). Variations of glycaemia have been observed under several different environmental and physiological conditions, including hypoxia (Hagerman et al., 1990; Hall and Van Ham, 1998; Schmitt and Uglow, 1998; Racotta et al., 2002) and ammonia (Racotta and Hernandez-Herrera, 2000; Mugnier and Justou, 2004). In addition, the number of total haemocyte in the haemolymph, considered as an immunological indicator (Rodriguez and Le Moullac, 2000) was measured, haemocytes being involved in most of the immune mechanisms in crustacean (Johansson et al., 2000).

\section{Material and methods}

\subsection{Experimental animals (Table 1)}

The experiment was conducted on three occasions -referred as experiments E1 to E3- in the aquaculture facilities of IFREMER in New Caledonia, on the same population of juvenile (average weight $6.3 \pm 0.1 \mathrm{~g}, \mathrm{~N}=744$ ) L. stylirostris reared in an earthen pond. For each experiment, shrimp were transported to eight 200 I indoor tanks (29-32 shrimp per tank) with aerated sea water. Mean temperatures and salinities are reported in Table 1 . They were acclimated at least for 5 days before the experiment started (Soyez, 1997) and were fed commercial pellets. Shrimp were not fed $12 \mathrm{~h}$ before and during the experiment and water renewal was stopped during the experiment.

\subsection{Moult stage determination}

Six moult stages were defined according to the retraction of the epithelium within setae of the antennal scale (Drach, 1939; Chan et al., 1988). Shrimp were classified as A and B respectively for the early and late post molt stages, $C$ for intermolt and $D_{0}, D_{1}, D_{2}$ for premolt stages. $D_{2}$ was the late premolt stage prior to ecdysis, when epidermis is at maximal retraction and it is possible to distinguish the developing seta.

\subsection{Experimental procedure}

Experimental conditions of temperature, salinity, osmotic pressure and $\mathrm{pH}$ are reported in Table 1.

Shrimp were exposed for $24 \mathrm{~h}$ either to a theoretical sub-lethal concentration of $2.0 \mathrm{mg} \mathrm{NH}_{3}-\mathrm{N} \mathrm{I}^{-}$ ${ }^{1}$ (Chen and Lei, 1990; Chen and Lin, 1992; Mugnier and Justou, 2004), or a sub-lethal hypoxia of $1.5 \mathrm{mg} \mathrm{O}_{2} \mathrm{I}^{-1}$ (4.3 kPa) (Allan and Maguire, 1991; Martinez et al., 1998; Mugnier and Soyez, 2005), or a combination of both. In this way, four treatments were obtained: Control, ammonia alone, hypoxia alone and combined ammonia and hypoxia $\left(\mathrm{A}+\mathrm{O}_{2}\right)$ with two tanks (replicates) for each treatment.

\subsubsection{Hypoxia}

Dissolved oxygen (DO) concentration was maintained to saturation (6-7 $\mathrm{mg} \mathrm{I}^{-1}, 17.7-20.4 \mathrm{kPa}$ ) before the experiment started and during the experiment for control shrimp. Tanks submitted to hypoxia were coupled by a PVC pipe and an immerged pump permitting a common recirculation of seawater. The surface of the water in both tanks was covered with a plastic film to limit gas exchange at the surface. A pH and oxygen probes placed in the PVC pipe were connected to a controller (Consor multichannel controller R305). Nitrogen gas was bubbled into the water till the DO reached the desired concentration of $1.5 \mathrm{mg} \mathrm{O}_{2} \mathrm{I}^{-1}(4.3 \mathrm{kPa})$ in approximately one hour. Nitrogen gas was then stopped and the required DO concentration was maintained by continuous monitoring of oxygen pressure $\left(\mathrm{PO}_{2}\right)$ with the controller switching on or off an air pumping device to adjust oxygen level. Shrimp were maintained during $24 \mathrm{~h}$ at the concentrations cited. Actual values obtained during the experiments are presented in Table 2. 


\subsubsection{Ammonia}

Ammonia test solutions were prepared by dissolving the required amount of ammonium chloride in seawater. The amount of ammonium chloride to be added to obtain a $\mathrm{NH}_{3}-\mathrm{N}$ concentration of $2.0 \mathrm{mg} \mathrm{I}^{-1}$ was calculated according to the equilibrium equation of Bower and Bidwell (1978)

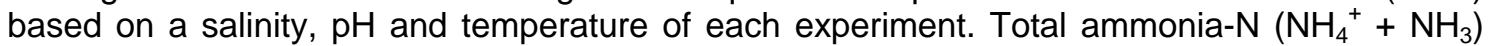
concentrations in the water sampled at the end of the experiment were measured by the Koroleff method (1976) adapted to seawater. Absorbance was read at $630 \mathrm{~nm}$ on a Spectronic Genesys ${ }^{\mathrm{TM}}$ spectrophotometer. Final $\mathrm{NH}_{3}-\mathrm{N}$ concentrations were calculated according to the equation of Bower and Bidwell (1978) based on the mean salinity, $\mathrm{pH}$ and temperature of the water in tanks, calculated over the $24 \mathrm{~h}$ of the experiment. Actual values obtained during the experiments are presented in Table 3. The consequence of lower $\mathrm{pH}$ and temperature in E1 compared to E2/E3 was a higher ammonia concentration needed to obtain a theoretical $\mathrm{NH}_{3}$ level of $2 \mathrm{mg}^{-1} \mathrm{I}^{-1}$.

When coupled with hypoxia, ammonium chloride was added to the tanks during the decrease of DO concentration. Temperature and $\mathrm{pH}$ were measured several times during the experiment and $\mathrm{NH}_{3}-\mathrm{N}$ concentration was maintained as close as possible to the desired value by maintaining the initial $\mathrm{pH}$, which tended to decrease, by adding $\mathrm{NaOH}$ to the tanks. However, uncontrollable drifts of $\mathrm{pH}$ occurred during the night, especially in $\mathrm{E} 1$ where the drop of $\mathrm{pH}$ was not anticipated as in experiments E2 and E3, conducting to a lower average concentration of $\mathrm{NH}_{3}-\mathrm{N}$.

\subsubsection{Shrimp sampling}

The molt stage of all shrimp was determined, but only shrimp in molt stages $C$ and $D_{2}$ were sampled for haemolymph analysis. After $24 \mathrm{~h}$ of exposure to each treatment, haemolymph samples of shrimp were collected in the ventral sinus using disposable syringes and needles and were immediately distributed as follows: A 10- $\mu$ l subsample of haemolymph was used for measurement of osmotic pressure with a vapour pressure Wescor osmometer. Osmotic pressure of the water $(10 \mu \mathrm{l})$ was also measured as for the haemolymph, with the Wescor osmometer. A 10- $\mu$ l subsample was diluted in $390 \mu \mathrm{l}$ of distilled water and oxyhaemocyanin absorbance was directly measured at $335 \mathrm{~nm}$ (characteristic of oxyhaemocyanin) using a Lightwave S1000 spectrophotometer. A $10-\mu \mathrm{l}$ subsample was diluted in $30 \mu \mathrm{l}$ anticoagulant solution (trisodium citrate $30 \mathrm{mM}, \mathrm{NaCl} 338 \mathrm{mM}$, glucose $115 \mathrm{mM}$, EDTA $10 \mathrm{mM}, \mathrm{pH}$ 7) containing $10 \%(\mathrm{v} / \mathrm{v})$ formalin for numeration of heamoytes. A $45-\mu \mathrm{l}$ subsample of haemolymph was mixed with $5 \mu \mathrm{l}$ of $10 \%$ sodium citrate and centrifuged $5 \mathrm{~min}$ at $800 \mathrm{~g}, 5^{\circ} \mathrm{C}$. The supernatant (plasma) was stored at $-80^{\circ} \mathrm{C}$ for further biochemical analysis.

When observed, dead shrimp were removed from the tanks and their molt stage determined. Molted exoskeletons were collected in tanks and occurrence of molting was recorded in experiments E2 and E3.

\subsection{Plasma constituent analysis}

Numeration of haemocytes was carried out within $72 \mathrm{~h}$ following sampling using an inverted phase contrast microscope (Leica).

A $25 \mu \mathrm{l}$ sub-sample of plasma was mixed with $50 \mu \mathrm{l}$ ice-cold $6 \% \mathrm{v} / \mathrm{v}$ perchloric acid and centrifuged for $15 \mathrm{~min}$ at $13000 \mathrm{~g}$ for deproteinisation. The supernatant was neutralized with $7 \mu \mathrm{l}$ of $\mathrm{KOH} 3 \mathrm{M}$ (Paterson, pers. com.). Commercial kits (Biomérieux) adapted to a microplate were used for glucose, lactate, magnesium and calcium determinations. Absorbance was read on a microplate reader (Digiscan Asys Hitech 340), and concentrations were calculated from a standard curve of substrate. Glucose and lactate were assayed on deproteneized plasma. Plasma level of total proteins was measured by the Lowry et al. (1951) technique adapted to microplate method, using bovine serum albumin (Sigma, molecular weight: 66,000 daltons) as a standard. 


\subsection{Data and statistical analysis}

The OC was calculated as the difference in mOsm kg-1 of osmotic pressure between seawater and shrimp haemolymph. The oxyhaemocyanin concentration was calculated using an extinction coefficient ( $\left.E^{\mathrm{mM}}{ }_{1 \mathrm{~cm}}\right)$ of 17.26 (Chen and Cheng, 1993b).

Data are plotted as mean \pm standard error. They were analysed with three-way (treatment $x$ molt stage $x$ experiment) ANOVA, taking into account first-order interactions. The experiment effect stands for a measure of reproducibility allowing to take into account mean variations across experiments, and the effect of these variations according to the treatment through the treatment $x$ experiment interaction. Significance of treatment effects was assessed through mean squares comparison with interaction terms: a significant interaction term will not be considered if the corresponding mean square is low compared to the mean squares of the main effect. Between-mean comparisons were performed using the Fisher's PLSD test at 5\% significant threshold (Statview computer software). No data on glucose and lactate concentrations were available for shrimp in stage $D_{2}$ submitted to hypoxia treatment in E2. Therefore, this treatment was not included in the statistical analysis for these two parameters. Mortalities were compared by Chi-square tests at $5 \%$ significant threshold.

Molt stages repartitions were also analysed by Chi-square tests at $5 \%$ significant threshold.

\section{Results}

\subsection{Effect of short-term exposure to ammonia-N and/or hypoxia on mortality (Table 4)}

No mortality was recorded for control shrimp. Low but significant mortalities were observed in shrimp submitted to ammonia (4.8\%) and hypoxia (3.0\%), and especially when hypoxia and ammonia were combined (11.6\%). This mortality was significantly higher than the one obtained with ammonia only $(p=0.03)$ or hypoxia only $(p=0.003)$, which were not different between them $(p=0.4)$ (Table 4). The main stage affected by mortality was the early postmolt stage A (6 out of the 8 dead shrimp) for ammonia treatment, associated with stage $D_{2}$. In the hypoxia treatment, 3 shrimp out of the 5 dead animals observed could not be identified. The two other dead shrimp were in late postmolt stage $D_{2}$. Except for one dead shrimp in stage $B$, all the dead shrimp $(95 \%)$ were in stage $D_{2}$ in the $A+O_{2}$ treatment (Table 4).

\subsection{Effect of short-term exposure to ammonia- $\mathrm{N}$ and/or hypoxia on molt stages distribution (Table 5)}

Distribution of shrimp in the different molt stages at the end of the experiments are presented in Table 5. Except for E3 in the control group, where a low percentage of stage A was observed $(1.6 \%)$, ammonia was the only treatment where this stage could be observed. Molted exoskeletons collected (E2 and E3) corresponded to the number of shrimp in stage A. The molt stage distribution was significantly different from control $\left(\mathrm{Chi}^{2}, \mathrm{p}<0.05\right)$ in E1 and E3 (Table 5). Percentage of shrimp in stage B was also twice higher in ammonia treatment of E1 than in control $(p<0.05)\left(\right.$ Table 5), while the percentage of shrimp in stage $D_{1}$ was three times lower (Table 5). A significantly higher percentage of shrimp in stage $D_{1}$ was also observed in shrimp submitted to hypoxia compared to control in the third experiment $(64.3 \%$ against $31.1 \%$, Table 5). No significant differences were observed in the treatment $A+O_{2}$.

\subsection{Effect of short-term exposure to ammonia-N and/or hypoxia and molt stage on haemolymph constituents (Fig. 1)}

Significant results of the statistical analysis are reported in Table 6. Strong interactions between treatment and molt stage, relatively to the treatment effect (Table 6) are observed for $\mathrm{Ca}^{2+}$, glucose and lactate. Moreover, significance of the treatment effect cannot be considered for $\mathrm{Mg}^{2+}$ and glucose due to a strong Treatment $\mathrm{x}$ experiment interaction. Most mean values vary across experiments. 
All treatments led to a significant decrease of OC (Fig. 1A), which is lower in premolt shrimp compared to intermolt shrimp, whatever the treatment (Fig. 2A). For stage $C$, the decrease varied between $26 \%$ (hypoxia) and $29 \%\left(A+O_{2}\right)$, while for stage $D_{2}, O C$ was reduced of $66 \%$ of the control value in $\mathrm{A}+\mathrm{O}_{2}$ treatment, compared to $39-41 \%$ in hypoxia and ammonia treatments (Fig. 1A).

Although significance of the treatment effect cannot be considered, an increase of 1.3 to 1.5 times in $\mathrm{Mg}^{2+}$ was observed for all treatments in both stages $C$ and $D_{2}$ (Fig. 1B). At the same time, plasmatic concentration of $\mathrm{Ca}^{2+}$ increased slightly but significantly for all treatments (Fig. 1C). $\mathrm{Mg}^{2+}$ concentration was higher in premolt shrimp than in intermolt shrimp.

In ammonia and hypoxia treatments, glucose levels were 1.4-1.6 times higher in premolt shrimp compared to intermolt shrimp, while the basal level in control was similar (48.8 $\mathrm{mg} \mathrm{dl}^{-1}$ in intermolt against $50.5 \mathrm{mg} \mathrm{dl}^{-1}$ in premolt shrimp) (Fig. 1D). Significant increases of respectively 2.2 and 1.3 fold in lactate concentration were observed in premolt and intermolt shrimp submitted to $\mathrm{A}+\mathrm{O}_{2}$ treatment. The level increased 1.5 fold in premolt shrimp submitted to hypoxia (Fig. 1E). Lactate levels were 1.8 times higher in ammonia and $\mathrm{A}+\mathrm{O}_{2}$ treated premolt shrimp (Fig. 1E) compared to intermolt shrimp, while the ratio was 1.1 in control shrimp.

A significant decrease in total proteins compared to control was observed in ammonia and $\mathrm{A}+\mathrm{O}_{2}$ treatments (respectively 19 and $9 \%$ for premolt shrimp) (Fig. 1F).

No significant decreases were observed for the oxyhaemocyanin concentration compared to the control for all treatments. However, the concentration was significantly lower in shrimp submitted to hypoxia compared to $\mathrm{A}+\mathrm{O}_{2}$ treatment (Fig. 1G).

Eventually, a significant decrease of THC was observed in shrimp submitted to hypoxia and $\mathrm{A}+\mathrm{O}_{2}$ treatment (respectively $28 \%$ and $36 \%$ in premolt shrimp) (Fig. $1 \mathrm{H}$ ). THC was 1.35 times higher in premolt shrimp compared to intermolt shrimp in control and ammonia groups. For oxyhaemocyanin and THC, the effect of molt stage is independent of the treatment (Table 6).

\section{Discussion}

Statistical analysis by three-way ANOVA showed an effect of experiment on some of the physiological indicators used in this study. For OC, the experiment effect can be explained by a lower salinity (and thus osmotic pressure of the water) in E1 compared to E2 and E3 (Table 1), leading to a lower OC. Total protein level and glucose were also higher in E1 compared to E2 and E3. This difference could reflect different nutritional conditions (Pascual et al., 2003) in the outdoor pond between E1 and E2-E3 which were conducted closely. $\mathrm{Ca}^{2+}$ concentration was lower in E2 compared to E1 and E3 but so far no explanation can be given.

\subsection{Ammonia levels and effect on shrimp}

The difference between the expected value of $\mathrm{NH}_{3}-\mathrm{N}$ and the values actually obtained led to a shift of $0.4 \mathrm{mg} \mathrm{I}^{-1}$ above the expected value $\left(2.4 \mathrm{mg} \mathrm{I}^{-1}\right)$ for ammonia treatment and below (1.6 $\mathrm{mg} \mathrm{l}^{-1}$ ) for $\mathrm{A}+\mathrm{O}_{2}$ treatment. It was mainly due to the difficulty to control pH over $24 \mathrm{~h}$ in the tanks. $\mathrm{pH}$ is the main factor affecting the equilibrium between ionized and unionized forms of ammonia- $\mathrm{N}$. $\mathrm{pH}$ has also an effect on the kinetic of ammonia accumulation in hamolymph. Higher $\mathrm{pH}$ increase the uptake of ammonia- $\mathrm{N}$ as shown in P. japonicus (Chen and Kou, 1991), P. monodon (Chen and Kou, 1993) and the crayfish Pacifastacus leniusculus (Harris et al., 2001), and decreased ammonia-N excretion in P. chinensis (Chen and Lin, 1995). Without an automated system to regulate $\mathrm{pH}$ over $24 \mathrm{~h}$, drift could not be avoided during night.

Ammonia treatment, but not hypoxia or the combination of both, seemed to have accelerated molting in shrimp over the $24 \mathrm{~h}$ of exposure. In addition to the present work, results of unpublished experiments where shrimp were subjected for $24 \mathrm{~h}$ to 1.63 (33.6 $\mathrm{mg} \mathrm{l}^{-1}$ total ammonia-N) or $2.74 \mathrm{mg} \mathrm{NH}_{3}-\mathrm{N}^{-1}\left(66.5 \mathrm{mg} \mathrm{l}^{-1}\right.$ total ammonia-N) showed also a different repartition of molt stages compared to control, with the presence of shrimp in stage A (while not observed in the control), and significantly more shrimp in stage $D_{2}$ in one case, and in stage $B$ in the other. An effect of ammonia treatment on molt frequency was reported by Chen and Kou (1992): In Marsupenaeus japonicus exposed to $30 \mathrm{mg} \mathrm{I}^{-1}$ total ammonia- $\mathrm{N}$, molt cycle duration was reduced by $50 \%$. As molt cycle in juvenile L. stylirostris (around $6 \mathrm{~g}$ weight) at $24-26^{\circ} \mathrm{C}$ lasts about a week, and $D_{2}$ stage counts for 1-2 days (personal observation), a shift from D1 to 
molting and stage $A$ in 24 h does not seem unlikely, nor a shift from $D_{2}$ to $B$, stage $A$ lasting a couple of hours. One could ask why such an effect could not be observed in the $\mathrm{A}+\mathrm{O} 2$ treatment. A hypothesis is that, as observed in P. semisculatus submitted to $2 \mathrm{ppm}$ oxygen for 17 days Clark (1986), hypoxia inhibits molting. Clark (1986) observed that when oxygen was brought back to $5 \mathrm{ppm}$, molting was triggered. In E3, the significantly higher percentage of shrimp in stage D1 observed in the hypoxia treatment compared to the control could suggest such an effect, even if this result is not sufficient to conclude, and proper experiments need to be conducted.

Ammonia treatment led to a low but significant mortality. In a previous experiment no mortality was recorded for a 24h exposure to $1.79 \mathrm{mg} \mathrm{I}^{-1} \mathrm{NH}_{3}-\mathrm{N}$ (54.6 mg I $\mathrm{I}^{-1}$ total ammonia-N) (Mugnier and Justou, 2004). No mortalities were also recorded in adolescent $P$. monodon (5g) exposed

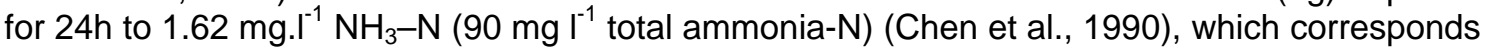
to the $\mathrm{NH}_{3}-\mathrm{N}$ concentration obtained in the $\mathrm{A}+\mathrm{O}_{2}$ treatment. As the level of $\mathrm{NH}_{3}-\mathrm{N}$ was higher in the Ammonia treatment of the present study, it is possible that it reached the lethal level. However, values are below the $24 \mathrm{~h} \mathrm{LC}_{50}$ observed for $\mathrm{P}$. chinensis $\left(3.88 \mathrm{mg} . \mathrm{I}^{-1} \mathrm{NH}_{3}-\mathrm{N}\right)$ (Chen and Lin, 1992) or P. monodon (2.68 mg. $\mathrm{I}^{-1} \mathrm{NH}_{3}-\mathrm{N}$ ) (Chen and Lei, 1990).

Results of the three experiments suggest that the toxic effect of ammonia was due to the unionized form rather than total ammonia. Indeed, the first experiment did not give higher mortality than the two following experiments, despite higher levels of total ammonia- $\mathrm{N}\left(62.3 \mathrm{mg} \mathrm{I}^{-1}\right.$ in E1 against $44 \mathrm{mg} \mathrm{I}^{-1}$ in E2 and E3 for ammonia treatment, and $71.5 \mathrm{mg} \mathrm{l}^{-1}$ against $44 \mathrm{mg} \mathrm{l}^{-1}$ for $\mathrm{A}+\mathrm{O}_{2}$ treatment).

Shrimp exposed to ambient ammonia accumulate ammonia in the haemolymph (Chen and Kou, 1993; Chen and Lin, 1995; Mugnier and Justou, 2004), which affects their physiology. Decrease of total proteins, also observed in $\mathrm{P}$. monodon exposed to ambient ammonia- $\mathrm{N}$ greater than $4.631 \mathrm{mg} \mathrm{l}^{-1}$ (Chen and Cheng, 1993a), is probably a result of proteolysis as evidenced by an increase in free amino acids in P. monodon (Chen et al., 1994). However protein decreased did not come with a significant oxyhaemocyanin decrease in haemolymph as observed in $\mathrm{P}$. monodon (Chen and Cheng, 1993a).Lin et al. (1993) suggested that decrease in OC due to ammonia treatment in $\mathrm{M}$. japonicus was the result of an impaired $\mathrm{Na}^{+}$and $\mathrm{Cl}^{-}$regulation. In the lobster H. americanus exposed to ammonia, Young-Lai et al. (1991) observed that the decrease of OC was caused by lower haemolymph sodium concentrations and that ammonia in external medium could affect the $\mathrm{Na}^{+} / \mathrm{NH}_{4}{ }^{+}$transport mechanism by impairing the transport sites for sodium. $\mathrm{Ca}^{2+}$ is implied in haemolymph buffering (McMahon, 2001), but its role in the physiological response of shrimp to ammonia is, to our knowledge, not documented. Significance of hyperglycaemia cannot be taken into account. However, hyperglycaemia in shrimp treated with ammonia was previously observed in L. stylirostris (Mugnier and Justou, 2004) and is a consequence of stress, hyperglycaemia being an indicator of a wide range of perturbations (Hall and Van Ham, 1998; Van Ham and Hall, 1998; Pascual et al., 2003).The lack of significant variation in THC was also observed by Liu and Chen (2004) in L. vannamei after $48 \mathrm{~h}$ exposure to $20 \mathrm{mg} \mathrm{l}^{-1}$ total ammonia- $\mathrm{N}$ (around $0.78-1.86 \mathrm{mg} \mathrm{I}^{-1} \mathrm{NH}_{3}$ ). However, one cannot conclude that immune system was not affected. These authors observed variations in other immune parameters and suggested that eventually ammonia caused a depression in the immune response of shrimp.

\subsection{Hypoxia}

As for ammonia exposure, hypoxia led to a low but significant mortality. As in $L$. vannamei (Charmantier et al., 1994), hypoxia led to an impaired osmoregulation as shown by a decrease of OC. The lack of statistical analysis does not permit to conclude about the significance of the increase of lactate and glucose observed in this treatment. However, in $\mathrm{L}$. vannamei exposed to hypoxic conditions $\left(1.5-2.5 \mathrm{mg} \mathrm{O}_{2} \mathrm{I}^{-1}\right)$ for three days, about 4-fold higher levels of glucose and lactate in haemolymph were observed compared to control (Racotta et al., 2002). Increased haemolymph lactate concentration commonly released from anaerobic tissue metabolism in crustaceans increases haemocyanin $\mathrm{O}_{2}$-binding affinity (McMahon, 2001). Increase of both $\mathrm{Mg}^{2+}$ and $\mathrm{Ca}^{2+}$ concentrations has been associated with increased oxygen affinity (McMahon, 2001). Under hypoxia, increased haemolymph $\mathrm{Ca}^{2+}$ concentration is an important factor in adjusting haemolymph oxygen affinity (McMahon, 2001). Anaerobic metabolism leads to acidosis, and part of the increase of circulating $\mathrm{Ca}^{2+}$ could be to buffer the haemolymph (Hagerman and Uglow, 1982). No significant variation in oxyhaemocyanin was observed in our 
study. Hagerman et al. (1990) observed a reduced concentration of oxyhaemocyanin in the lobster exposed to $1.5 \mathrm{mg} \mathrm{O}_{2} \mathrm{I}^{-1}$ due to catabolism. Several works tend to show that increase in haemocyanin under hypoxia is observed only after long-term hypoxia (at least 7 days) (Hagerman et al., 1990; Racotta et al., 2002). The decrease of THC was also observed by Le Moullac et al (1998) in L. stylirostris submitted to $1 \mathrm{mg} \mathrm{O}_{2} \mathrm{l}^{-1}$. Hypoxia led to a stress response, and the reduced THC suggests also that the immune system was affected. Direkbusarakom and Danayadol (1998) showed a negative effect of hypoxia (1.8-2 $\mathrm{mg} \mathrm{O}_{2} \mathrm{I}^{-1}$ ) on the immune system of $P$. monodon. Jiang et al. (2005) reported also a negative effect of hypoxia (3.5 and $2.0 \mathrm{mg} \mathrm{O}_{2} \mathrm{I}^{-1}$ ) on the immune system, including THC, of $\underline{L}$. vannamei. Hypercapnic hypoxia

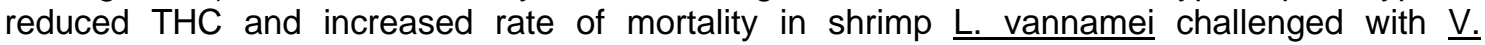
parahaemolyticus (Mikulski et al., 2000).

\subsection{Combined effect of ammonia + hypoxia}

Ammonia or hypoxia treatments had a limited effect on shrimp mortality, while the combination of both, despite the fact that the value of each parameter was lower when combined did not lead to cumulative mortalities but gave a synergic effect. The lower concentration of $\mathrm{NH}_{3}-\mathrm{N}$ obtained in the A+O2 treatment (respectively $1.59 \mathrm{mg} \mathrm{NH}_{3}-\mathrm{N}^{-1}$ against $2.39 \mathrm{mg} \mathrm{l}^{-1}$ in ammonia treatment), and higher oxygen concentration (1.6 mg O $\mathrm{I}^{-1}$ against $1.4 \mathrm{mg} \mathrm{I}^{-1}$ in hypoxia treatment) re-enforce the synergic influence that should be even more pronounced if similar levels were obtained.

Allan and Maguire (1990) observed also a synergic effect of ammonia (1.6 $\mathrm{mg} \mathrm{NH}_{3} \mathrm{I}^{-1}$ ) and hypoxia $\left(2.3 \mathrm{mg} \mathrm{O}_{2} \mathrm{I}^{-1}\right)$ on P. monodon mortality over $96 \mathrm{~h}$. In $\mathrm{P}$. semisculatus, exposure to 1.8 $\mathrm{mg} \mathrm{O}_{2} \mathrm{I}^{-1}$ doubled the toxicity of ammonia (Wajsbrot et al., 1990). However, these authors suggested an additive effect of low oxygen and ammonia toxicity.

Hypoxia seems to reduce the tolerance of shrimp to $\mathrm{NH}_{3}-\mathrm{N}$. In another experiment realized in the same conditions, the combination of a concentration of $2.93 \mathrm{mg} \mathrm{I}^{-1} \mathrm{NH}_{3}-\mathrm{N}$ with a DO concentration of $1.0 \mathrm{mg} \mathrm{O}_{2} \mathrm{I}^{-1}$ killed all the shrimps, while separately mortality rates for ammonia treatment $\left(2.74 \mathrm{mg} \mathrm{I}^{-1} \mathrm{NH}_{3}-\mathrm{N}\right)$ and hypoxia $\left(0.8 \mathrm{mg} \mathrm{O}_{2} \mathrm{I}^{-1}\right)$ were not significant (respectively 3.6 and 6.8\%, unpublished results). Allan et al. (1990) also observed that low DO $\left(2.2 \mathrm{mg} \mathrm{O}_{2} \mathrm{l}^{-1}\right)$ increased ammonia toxicity, especially for $\mathrm{NH}_{3}-\mathrm{N}$ concentrations around $1.60 \mathrm{mg} \mathrm{I}^{-1}$ compared to $1.30 \mathrm{mg} \mathrm{l}^{-1}$. The present results do not permit to understand the mechanisms of toxicity. However, it is interesting to notice that hyperventilation in response to acute hypoxia (up to $24 \mathrm{~h}$ ) is observed in most crustaceans, and that hyperventilation induce alkalosis (Burnett and Johansen, 1981; Hagerman and Uglow, 1985, McMahon, 2001, Cheng et al., 2003c). Coupled with a high concentration of ammonia- $\mathrm{N}$ in the haemolymph, the increased $\mathrm{pH}$ could conduct to a higher concentration of the toxic form $\mathrm{NH}_{3}$ in the haemolymph, and, in turn, higher toxicity. No data are available on L. stylirostris hyperventilation and induced alkalosis, but one can expect this kind of response.

Exposure to high ambient ammonia- $\mathrm{N}$ concentrations increases also oxygen consumption in penaeid species (Chen and Lin, 1995; Racotta and Hernandez-Herrera, 2000). As it has been previously observed in L. stylirostris exposed to the same range of ammonia- $\mathrm{N}$ that in this study $\left(54.6 \mathrm{mg} \mathrm{l}^{-1}\right)$, an uptake of ammonia- $\mathrm{N}$ led to a final haemolymph concentration equivalent to $84 \%$ (stage C) to $93 \%$ (stage D2) of the ambient ammonia- $\mathrm{N}$ concentration (Mugnier and Justou, 2004). However, the increase in lactate level observed after 24h in $\mathrm{A}+\mathrm{O} 2$ treatment, but not in shrimp exposed to ambient ammonia- $\mathrm{N}$, suggests an anaerobic metabolism (Hagerman et al., 1990) with a possible acidosis. A first step to understand the mechanisms which occur could be to measure the haemolymph $\mathrm{pH}$ and respiratory products of shrimp submitted to the different treatments regularly from the beginning of the experiment, and observe if alkalosis occurs first with a possible enhancement of the toxic effect of $\mathrm{NH}_{3}$, and if it is followed by acidosis due to anaerobic metabolism. In this case, mortality due to $\mathrm{NH}_{3}$ toxicity could be observed before the $\mathrm{pH}$ is reduced due to anaerobic metabolism.

Exposure to the combination of ammonia and hypoxia led to a stress response characterized by stronger decrease in $\mathrm{OC}$ and increase in $\mathrm{Ca}^{2+}$ and lactate, while variations in total proteins was intermediate between ammonia and hypoxia treatments, and THC was close to the one observed for hypoxia treatment. Physiological indicators such as oxyhaemocyanin were not different from the control. As oxyhaemocyanin concentration did not decrease, the decrease of total proteins in the haemolymph is not due to a catabolism of this protein. 


\subsection{Internal effect due to molt cycle}

The highest susceptibility to stress was observed just before and during molt: dead shrimp were either just before (stage $D_{2}$ ) or just after ecdysis (stage A). Ammonia treatment killed mainly shrimp in early postmolt stage $A$, and in a less extend shrimp in late premolt stage $D_{2}$. This result is consistent with the observations of Lin et al. (1993) on M. japonicus, and the observation made by Wajsbrot et al. (1990), who observed that just before and after molting $\underline{P}$. semisculatus was more sensitive to ammonia. All of the hypoxia-related dead shrimp which molt stage could be identified were in premolt stage $D_{2}$. These results are consistent with a previous work on $\underline{L}$. stylirostris submitted to $\left.1 \mathrm{mg} \mathrm{O}_{2}\right|^{-1}$ where the most sensitive stages were first stage $D_{2}$ and then B (Mugnier and Soyez, 2005). Allan and Maguire (1991) observed in juvenile of $\underline{P}$. monodon submitted to 2.1 and $1 \mathrm{mg} \mathrm{O}_{2} \mathrm{I}^{-1}$ that the few shrimp which did molt died within $4 \mathrm{~h}$. Nearly all the shrimp that died under the treatment $A+O_{2}$ were in late premolt stage $D_{2}(95 \%)$. The lack of shrimp in stage A did not permit to conclude about the sensitivity of shrimp after molting.

Shrimp in late premolt stage $D_{2}$ presented a stronger physiological response to treatments that intermolt animals, especially for $\mathrm{A}+\mathrm{O}_{2}$ treatment, indicating that they were more sensitive to environmental perturbation. This difference between intermolt and premolt animals was already observed for $\underline{L}$. stylirostris exposed to ambient ammonia (Mugnier and Justou, 2004) or hypoxia for OC (Mugnier and Soyez, 2005). In controlled conditions, shrimp in late premolt stage have a reduced osmoregulatory capacity than shrimp in intermolt stage (Charmantier et al., 1994). During molting, integument permeability increase and dependence on external factors is important.

The decreased THC observed in premolt shrimp -but not in intermolt shrimp- submitted to hypoxia and $\mathrm{A}+\mathrm{O}_{2}$ suggests that immunity of molting animals is affected by stress. Le Moullac et al (1998) have shown that $\underline{L}$. stylirostris is less resistant to pathogenic bacterial infection in premolt than in intermolt stage.

\section{Conclusion}

The more pronounced effects of ammonia coupled with hypoxia compared to the ammoniaalone and hypoxia-alone treatments show a synergic effect of cumulative stress on mortality. What if one or more perturbations were added? One could expect tolerance limits of these parameters to be lowered by a synergic effect. It is thus important in a pond to control all the parameters which may be stressful for shrimp, and the equilibrium between them. Definition of safe levels based on the study of combined environmental parameters such as ammonia, oxygen, nitrite, $\mathrm{pH}$ rather than isolated ones would be useful in order to permit a better management of the pond ecosystem.

These observations: higher mortality rate, physiological and immunological impaired states confirm that shrimp are more sensitive to environment -and presumably less resistant to bacteria- around molting.

Environmental perturbations not only affect the physiology of shrimp, but also the immune system.

\section{Acknowledgements}

This work was supported by research grants from the North and South Provinces of New Caledonia. The authors would like to thank P. Brun, E. Pita and C. Lambert for pond management; D. Ansquer, S. de Decker and A.L. Marteau who helped to sample the shrimps; J.M. Ranouil and J.S. Lam for technical assistance, and B. Beliaeff for valuable comments on statistical analysis. 


\section{References}

Allan, G. L., Maguire, G. B., Hopkins, S. J., 1990. Acute and chronic toxicity of ammonia to juvenile Metapenaeus macleayi and Penaeus monodon and the influence of low dissolvedoxygen levels. Aquaculture 91, 265-280.

Allan, G. L., Maguire, G. B., 1991. Lethal levels of low dissolved oxygen and effects of shortterm oxygen stress on subsequent growth of juvenile Penaeus monodon. Aquaculture 94, 2737.

Allan, G. L., Maguire, G. B., 1992. Effects of $\mathrm{pH}$ and salinity on survival, growth and osmoregulation in Penaeus monodon Fabricius. Aquaculture 107, 33-47.

Boglio, E., 1995. Measurement of stress in broodstock leader prawns (Penaeus monodon) following capture by trawling and transport to hatcheries. PhD, University of Queensland, Queensland. $155 \mathrm{pp}$.

Bower C.E., Bidwell J.P., 1978. Ionization of ammonia in seawater: effects of temperature, pH and salinity. Journal of the Fisheries Research Board of Canada 35, 1012-16.

Burgents J.E., Burnett K.G., Burnett L.E., 2005. Effects of hypoxia and hypercapnic hypoxia on the localization and elimination of Vibrio campbellii in Litopenaeus vannamei, the Pacific white shrimp. Biological Bulletin 208, 159-168.

Burnett L.E., Johansen K., 1981. The role of branchial ventilation in hemolymph acide-base changes in the shore crab Carcinus maenas during hypoxia. Journal of Comparative Physiology 141, 489-494.

Charmantier, G., Soyez, C., Aquacop, 1994. Effect of molt stage and hypoxia on osmoregulatory capacity in the penaeid shrimp Penaeus vannamei. Journal of Experimental Marine Biology and Ecology 178, 233-246.

Chan, S.-M., Rankin, S. M., Keeley, L. L., 1988. Characterization of the molt stages in Penaeus vannamei: setogenesis and hemolymph levels of total protein, ecdysteroids, and glucose. Biological Bulletin 175, 185-192.

Chen, J.-C., Cheng, S.-Y., 1993a. Hemolymph PCO2, hemocyanin, protein levels and urea excretions of Penaeus monodon exposed to ambient ammonia. Aquatic Toxiciology 27, 281292.

Chen J.-C. Cheng S.-Y., 1993b. Studies on haemocyanin and haemolymph protein levels of Penaeus japonicus based on sex, size and moulting cycle. Comparative Biochemistry and Physiology 106B(2): 293-296.

Chen, J.-C., Kou, Y.-Z., 1991. Accumulation of ammonia in the hemolymph of Penaeus japonicus exposed to ambient ammonia. Diseases of Aquatic Organisms 11, 187-191.

Chen, J.-C., Kou, Y.-Z., 1992. Effects of ammonia on growth and molting of Penaeus japonicus juveniles. Aquaculture 104, 249-260.

Chen, J.-C., Kou, Y.-Z., 1993. Accumulation of ammonia in the haemolymph of Penaeus monodon exposed to ambient ammonia. Aquaculture 109, 177-185.

Chen, J.-C., Chen, C.-T., Cheng, S.-Y., 1994. Nitrogen excretion and changes of hemocyanin, protein and free amino acid levels in the hemolymph of Penaeus monodon exposed to different concentrations of ambient ammonia- $\mathrm{N}$ at different salinity levels. Marine Ecology Progress Series 110, 85-94.

Chen, J.-C., Lei, S.-C., 1990. Toxicity of ammonia and nitrite to Penaeus monodon juveniles. Journal of the world aquaculture society $21,300-306$.

Chen, J.-C., Lin, C.-Y., 1992. Lethal effects of ammonia on Penaeus chinensis Osbeck juveniles at different salinity levels. Journal of Experimental Marine Biology and Ecology 156, 139-148.

Chen, J.-C., Lin, C.-Y., 1995. Responses of oxygen consumption, ammonia-N excretion and urea- $\mathrm{N}$ excretion of Penaeus chinensis exposed to ambient ammonia at different salinity and $\mathrm{pH}$ levels. Aquaculture 136, 243-255.

Chen, J.-C., Lin, J.-N., Chen, C.-T., Lin, M.-N., 1996. Survival, growth and intermolt period of juvenile Penaeus chinensis (Osbeck) reared at different combinations of salinity and temperature. Journal of Experimental Marine Biology and Ecology 204, 169-178.

Chen, J.-C., Liu, P.-C., Lei, S.-C., 1990. Toxicities of ammonia and nitrite to Penaeus monodon adolescents. Aquaculture 89, 127-137.

Chen, J.-C., Nan, F.-H., Cheng, S.-Y., Sheen, S.-S., 1993. Effects of ambient ammonia on ammonia- $\mathrm{N}$ and protein concentrations in hemolymph and ammonia- $\mathrm{N}$ excretion of Penaeus chinensis. Marine Ecology Progress Series 98, 203-208. 
Cheng, W., Chen, J.-C., 2002. The virulence of Enterococcus to freshwater prawn Macrobrachium rosenbergii and its immune resistance under ammonia stress. Fish and Shellfish Immunology 12, 97-109.

Cheng, W., Liu, C.-H., Hsu, J.-P., Chen, J.-C., 2002. Effect of hypoxia on the immune response of giant freshwater prawn Macrobrachium rosenbergii and its susceptibility to pathogen Enterococcus. Fish \& Shellfish Immunology 13, 351-365.

Cheng, W., Chen, S.-M., Wang, F.-I., Hsu, P.-I., Liu, C.-H., Chen, J.-C., 2003a. Effects of temperature, $\mathrm{pH}$, salinity and ammonia on the phagocytic activity and clearance efficiency of giant freshwater prawn Macrobrachium rosenbergii to Lactococcus garvieae. Aquaculture 219, 111-121.

Cheng, W., Juang, F.-M., Li, J.-T., Lin, M.-C., Liu, C.-H., Chen, J.-C., 2003b. The immune response of the giant freshwater prawn Macrobrachium rosenbergii and its susceptibility to Lactococcus garvieae in relation to the moult stage. Aquaculture 218, 33-45.

Cheng, W., Liu, C.-H., Kuo, C.-M., 2003c. Effects of dissolved oxygen on hemolymph parameters of freshwater giant prawn, Macrobrachium rosenbergii (de Man). Aquaculture 220, 843-856.

Chien, Y.-H., 1992. Water quality requirements and management for marine shrimp culture. In "World Aquaculture Society - proceedings of the special session on shrimp farming -" (J. Wyban, ed.), pp. 144-156. World Aquaculture Society, Baton Rouge, USA.

Clark, J. V., 1986. Inhibition of moulting in Penaeus semisulcatus (De Haan) by long-term hypoxia. Aquaculture 52, 253-254.

Claybrook D.L., 1983. Nitrogen metabolism. In: Mantel L.H. (ed.). The Biology of Crustacea, Vol. 5, Internal anatomy and physiological regulation. Academic Press, New York, pp.162-213.

Colt, J.E., Armstrong, D.A., 1981. Nitrogen toxicity to crustaceans, fish and molluscs. In: Allen, L.J., Kinney, E.C. (Eds.), Proceedings of the Bio-Engineering Symposium for Fish Culture. Fish Culture Section. American Fisheries Society, Northeast Society of Conservation Engineers, Bethesda, Maryland, pp. 34-47.

Costa, R., Mermoud, I., Koblavi, S., Morlet, B., Haffner, P., Berthe, F., LeGroumellec, M., Grimont, P., 1998. Isolation and characterization of bacteria associated with Penaeus stylirostris disease (syndrome 93) in New Caledonia. Aquaculture 164, 297-309.

Direkbusarakom, S., Danayadol, Y., 1998. Effect of oxygen depletion on some parameters of the immune system in black tiger shrimp (Penaeus monodon). In "Advances in shrimp biotechnology" (T. W. Flegel, ed.), pp. 147-149. National Center for Genetic Engineering and Biotechniology, Bangkok, Thailand.

Drach P., 1939. Mue et cycle d'intermue chez les crustacés décapodes. Annales de l'Institut Océanographique de Paris N. S. 19, 103-391.

Goarant, C., Ansquer, D., Herlin, J., Domalain, D., Imbert, F. De Decker, S., 2006. "Summer syndrome" in Litopenaeus stylirostris in New Caledonia: Pathology and epidemiology of the etiological agent, V. nigripulchritudo. Aquaculture 253: 105-113.

Hagerman, L., Uglow, R. F., 1982. Effects of hypoxia on osmotic and ionic regulation in the brown shrimp Crangon crangon (L.) from brackish water. Journal of Experimental Biology and Ecology 63, 93-104.

Hagerman, L., Uglow, R. F., 1985. Effects of hypoxia on the respiratory and circulatory regulation of Nephrops norvegicus under hypoxia. Marine Biology 87, 273-278.

Hagerman, L., Sondergaard, T., Weile, K., Hosie, D., Uglow, R. F., 1990. Aspects of blood physiology and ammonia excretion in Nephrops norvegicus under hypoxia. Comparative Biochemistry and Physiology 97A, 51-55.

Hall, M. R., van Ham, E. H., 1998. The effects of different types of stress on blood glucose in the giant tiger prawn Penaeus monodon. Journal of the World Aquaculture Society 29, 290-299.

Harris, R. R., Coley, S., Collins, S., McCabe, R., 2001. Ammonia uptake and its effects on ionoregulation in the freshwater crayfish Pacifastacus leniusculus (Dana). Journal of Comparative Physiology B 171, 681-693.

Horowitz, A., Horowitz, S., 2001. Disease control in shrimp aquaculture from a microbial ecology perspective. In: Browdy C.L., Jory D.E. (Eds.), Proceedings of the Special Session on Sustainable Shrimp Culture, Aquaculture 2001. The World Aquaculture Society, Baton Rouge, LA, USA, pp. 199-218.

Jiang, G., Yu, R., Zhou, M., 2004. Modulatory effects of ammonia-N on the immune system of Penaeus japonicus to virulence of white spot syndrome virus. Aquaculture 241, 61-75.

Jiang, L.-X., Pan, L.-q., Fang-Bo, 2005. Effect of dissolved oxygen on immune parameters of the white shrimp Litopenaeus vannamei. Fish and Shellfish Immunology 18, 185-188. 
Johansson, M. W., Keyser, P., Sritunyalucksana, K., Soderhall, K., 2000. Crustacean haemocytes and haematopoiesis. Aquaculture 191, 45-52.

Kir, M., Kumlu, M., Eroldogan, O. T., 2004. Effects of temperature on acute toxicity of ammonia to Penaeus semisulcatus juveniles. Aquaculture 241, 479-489.

Koroleff F., 1976. Determination of ammonia. In: Grasshof K. (Ed), Methods in seawater analysis, Verlag chemie, Weineim, RFA, pp. 126-133.

Le Moullac, G., Haffner, P., 2000. Environmental factors affecting immune responses in Crustacea. Aquaculture 191, 121-131.

Le Moullac, G., LeGroumellec, M., Ansquer, D., Froissard, S., Lecy, P., Aquacop, 1997. Haematological and phenoloxidase activity changes in the shrimp Penaeus stylirostris in relation with the moult cycle: protection against vibriosis. Fish and Shellfish Immunology 7, 227234.

Le Moullac, G., Soyez, C., Saulnier, D., Ansquer, D., Acvarre, J.-C., Levy, P., 1998. Effect of hypoxic stress on the immune response and the resistance to vibriosis of the shrimp Penaeus stylirostris. Fish and Shellfish Immunology 8, 621-629.

Li, Y., Li, J., Wang, Q., 2006. The effects of dissolved oxygen concentration and stocking density on growth and non-specific immunity factors in Chinese shrimp, Fenneropenaeus chinensis. Aquaculture 256, 608-616.

Lignot, J. H., Spanings-Pierrot, C., Charmantier, G., 2000. Osmoregulatory capacity as a tool in monitoring the physiological condition and the effect of stress in crustaceans. Aquaculture 191, 209-245.

Lin, Y.-C., Chen, J.-C., 2001. Acute toxicity of ammonia on Litopenaeus vannamei Boone juveniles at different salinity levels. Journal of Experimental Marine Biology and Ecology 259, 109-119.

Lin, H.-P., Thuet, P., Trilles, J., Mounet-Guillaume, R., Charmantier, G., 1993. Effects of ammonia on survival and osmoregulation of various development stages of the shrimp Penaeus japonicus. Marine Biology 117, 591-598.

Liu, C.-H., Chen, J.-C., 2004. Effect of ammonia on the immune response of white shrimp Litopenaeus vannamei and its susceptibility to Vibrio alginolyticus. Fish and Shellfish Immunology 16, 321-334.

Liu, C.-H., Yeh, S.-T., Cheng, S.-Y., Chen, J.-C., 2004. The immune response of the white shrimp Litopenaeus vannamei and its susceptibility to Vibrio infection in relation with the moult cycle. Fish and Shellfish Immunology 16, 151-161.

Lowry O.H., Rosebrough N.F., Farr A.L., Randall R.J., 1951. Protein measurement with the Folin phenol reagent. Journal of Biology and Chemistry 193, 251.

Martinez, E., Aguilar, M., Trejo, L., Hernandez, I., Diaz-Iglesia, E., Soto, L. A., Sanchez, A., Rosas, C., 1998. Lethal low dissolved oxygen concentrations for postlarvae and early juvenile Penaeus setiferus at different salinities and $\mathrm{pH}$. Journal of the World Aquaculture Society 29, 221-229.

Mauro, N. A., Thompson, C., 1984. Hypoxia adaptation in the crayfish Procambarus clarki. Comparative Biochemistry and Physiology 79A, 73-75.

McMahon B.R., 2001. Respiratory and circulatory compensation to hypoxia in crustaceans. Respiration physiology 128, 349-364.

Mermoud, I., Costa, R., Ferré, O., Goarant, C., Haffner, P., 1998. "Syndrome 93" in New Caledonian outdoor rearing ponds of Penaeus stylirostris: history and description of three major outbreaks. Aquaculture 164, 323-335.

Mikulski C.M., Burnett L.E., Burnett K.G., 2000. The effects of hypercapnic hypoxia on the survival of shrimp challenged with Vibrio parahaemolyticus. Journal of Shellfish Research 19, 301-311.

Morritt, D., Spicer, J. I., 1993. A brief re-examination of the function and regulation of extracellular magnesium and its relationship to activity in crustacean arthropods. Comparative Biochemistry and Physiology 106A, 19-23.

Mugnier, C., and Justou, C., 2004. Combined effect of external ammonia and molt stage on the blue shrimp Litopenaeus stylirostris physiological response. Journal of experimental Marine Biology and Ecology 309, 35-46.

Mugnier, C., Soyez, C., 2005. Response of the blue shrimp Litopenaeus stylirostris to temperature decrease and hypoxia in relation to molt stage. Aquaculture 244, 315-322.

Parado-Estepa, F. D., 1998. Survival of Penaeus monodon postlarvae and juveniles at different salinity and temperature levels. The Israeli Journal of Aquaculture - Bamidgeh 50, 174-183. 
Pascual, C., Gaxiola, G., Rosas, C., 2003. Blood metabolites and hemocyanin of the white shrimp, Litopenaeus vannamei: the effect of culture conditions and a comparison with other crustacean species. Marine Biology 142, 735-745.

Paul, R. J., Pirow, R., 1997/98. The physiological significance of respiratory proteins in invertebrates. Zoology 100, 298-306.

Racotta, I. S., Hernandez-Herrera, R., 2000. Metabolic responses of the white shrimp, Penaeus vannamei, to ambient ammonia. Comparative Biochemistry and Physiology A 125, 437-443.

Racotta I.S., Palacios E., Mendez L., 2002. Metabolic responses to short and long-term exposure to hypoxia in white shrimp (Penaeus vannamei). Mar. Fresh. Behav. Physiol. 35, 269275.

Rodriguez, J., Le Moullac, G., 2000. State of the art of immunological tools and health control of penaeid shrimp. Aquaculture 191, 109-119.

Schmitt, A. S. C., Uglow, R. F., 1997. Effects of ambient ammonia levels on blood ammonia, ammonia excretion and heart and scaphognathite rates of Nephrops norvegicus. Marine Biology 127, 411-418.

Schmitt, A. S., Uglow, R. F., 1998. Metabolic responses of Nephrops norvegicus to progressive hypoxia. Aquating Living Resources 11, 87-92.

Soyez, C., 1997. Evaluation des conséquences d'une situation hypoxique simulée sur la capacité osmorégulatrice des crevettes d'élevage, Penaeus stylirostris et Penaeus vannamei. Internal Report, COP IFREMER, Tahiti, $50 \mathrm{pp}$.

van Ham, E. H., Hall, M. R., 1998. The effects of prophylactic formalin bath treatment on blood glucose in the giant tiger prawn Penaeus monodon. Journal of the World Aquaculture Society 29, 357-364.

Wajsbrot, N., Gasith, A., Krom, M. D., Samocha, T. M., 1990. Effect of dissolved oxygen and the molt stage on the acute toxicity of ammonia to juvenile green tiger prawn Penaeus semisulcatus. Environmental Toxicology and Chemistry 9, 497-504.

Young-Lai, W. W., Charmantier-Daures, M., Charmantier, G., 1991. Effect of ammonia on survival and osmoregulation in different life stages of the lobster Homarus americanus. Marine Biology 110, 293-300.

Zhang, P., Zhang, X., Li, J., Huang, G., 2006. The effects of body weight, temperature, salinity, $\mathrm{pH}$, light intensity and feeding condition on lethal DO levels of whiteleg shrimp, Litopenaeus vannamei (Boone, 1931). Aquaculture 256, 579-587. 


\section{Tables}

Table 1: Experimental conditions, density, acclimation and weight of shrimp in the experiments E1 toE3.

E1

E2

E3

\begin{tabular}{lccc}
\hline Temperature $\left({ }^{\circ} \mathrm{C}\right)$ & $24.8 \pm 0.5$ & $25.9 \pm 0.2$ & $26.1 \pm 0.5$ \\
Salinity (\%) & 30.1 & 31.9 & 32.4 \\
Osmotic Pressure (mOsm kg- & 971 & 1025 & 1055 \\
$\left.{ }^{1}\right)$ & & & \\
$\mathrm{pH}$ & $7.74 \pm 0.21$ & $7.91 \pm 0.06$ & $7.82 \pm 0.31$ \\
Shrimp/tank & 29 & 32 & 32 \\
Acclimation period (days) & 5 & 7 & 6 \\
Mean weight (g) & $5.6 \pm 0.2$ & $6.6 \pm 0.2$ & $6.6 \pm 0.1$ \\
\hline
\end{tabular}

Table 2: Values of dissolved oxygen concentrations ( $\mathrm{mg}^{-I^{-1}}(\mathrm{kPa})$ ) in the experimentations (E1 to $\mathrm{E} 3)$ in relation to the treatment $\left(\mathrm{A}+\mathrm{O}_{2}\right.$ : ammonia + hypoxia).

\begin{tabular}{lccc}
\hline Treatment & E1 & E2 & E3 \\
\hline Control/Ammoni & $6.5(19.5)$ & $6.3(18.9)$ & $6.9(20.7)$ \\
$\mathrm{a}$ & $1.4(4.2)$ & $1.3(3.9)$ & $1.4(4.2)$ \\
$\mathrm{Hypoxia}$ & $1.4(4.2)$ & $1.6(4.8)$ & $1.9(5.7)$ \\
$\mathrm{A}+\mathrm{O}_{2}$ & & & \\
\hline
\end{tabular}


Table 3: Values of total ammonia- $\mathrm{N}$ (TAN) and $\mathrm{NH}_{3}-\mathrm{N}$ concentrations (mg..$^{-1}$ ) in the experimentations (E1 to $E 3)$ in relation to the treatment $\left(A+\mathrm{O}_{2}\right.$ : ammonia + hypoxia).

\begin{tabular}{lll}
\hline E1 & E2 & E3
\end{tabular}

\begin{tabular}{lcccccc}
\hline Treatment & TAN & $\mathrm{NH}_{3}-\mathrm{N}$ & TAN & $\mathrm{NH}_{3}-\mathrm{N}$ & TAN & $\mathrm{NH}_{3}-\mathrm{N}$ \\
\hline Control/Hypoxia & 0.7 & 0.03 & 0.7 & 0.04 & 1.2 & 0.04 \\
Ammonia & 62.3 & 2.41 & 44.0 & 2.31 & 44.5 & 2.46 \\
$\mathrm{~A}+\mathrm{O}_{2}$ & 71.5 & 1.23 & 44.0 & 1.79 & 44.5 & 1.76 \\
\hline
\end{tabular}

Table 4: Percentages of mortality and molt stage repartition of dead shrimp (in \% of all dead shrimp) in the different treatments over the $24 \mathrm{~h}$ experiment. (ND: unknown molt stage).

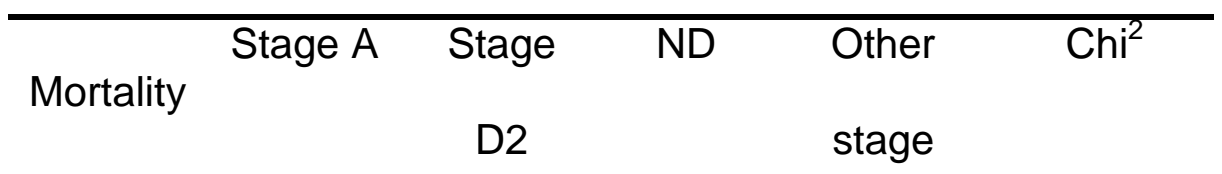

\begin{tabular}{lcccccc}
\hline Control & 0.0 & - & - & - & - & - \\
Ammonia & $4.8^{*, a}$ & 75 & 25 & 0 & 0 & ${ }^{*} \mathrm{p}=0.0023$ \\
Hypoxia & $3.0^{*, \mathrm{a}}$ & 0 & 40 & 60 & 0 & ${ }^{*} \mathrm{p}=0.0243$ \\
$\mathrm{~A}+\mathrm{O} 2$ & $11.6^{*, \mathrm{~b}}$ & 0 & 95 & 0 & $5(\mathrm{~B})$ & ${ }^{*} \mathrm{p}<0.0001$
\end{tabular}

* significantly different from Control $\left(\mathrm{Chi}^{2}, \mathrm{p}<0.05\right) ;{ }^{\mathrm{a}, 0}$ significantly different $\left(\mathrm{Chi}^{2}, \mathrm{p}<0.05\right)$ 
Table 5: repartition of molt stages (in percent) after $24 \mathrm{~h}$ of different treatments in the three experiments (E1 to E3).

\section{Molt stages}

Experimen Treatment

$\mathrm{t}$
C
$\mathrm{D}_{0}$
$D_{1}$
$D_{2}$
A
B

\begin{tabular}{|c|c|c|c|c|c|c|c|c|}
\hline & Control & & 32.7 & 20.0 & 32.7 & 7.3 & 0.0 & 7.3 \\
\hline \multirow[t]{5}{*}{ E1 } & Ammonia & & 27.1 & 18.7 & $10.4^{*}$ & 14.6 & $12.5^{*}$ & $16.7^{*}$ \\
\hline & Hypoxia & & 34.0 & 24.0 & 32.0 & 10.0 & 0.0 & 0.0 \\
\hline & Ammonia & + & 31.4 & 15.7 & 37.2 & 9.8 & 0.0 & 5.9 \\
\hline & Hypoxia & & & & & & & \\
\hline & Control & & 13.8 & 20.0 & 29.2 & 20.5 & 0.0 & 12.3 \\
\hline \multirow[t]{5}{*}{ E2 } & Ammonia & & 14.5 & 17.7 & 35.5 & 16.1 & 4.8 & 11.3 \\
\hline & Hypoxia & & 16.9 & 27.1 & 27.1 & 22.0 & 0.0 & 6.8 \\
\hline & Ammonia & + & 12.7 & 31.7 & 17.5 & 28.6 & 0.0 & 7.9 \\
\hline & Hypoxia & & & & & & & \\
\hline & Control & & 11.5 & 13.1 & 31.1 & 36.0 & 1.6 & 6.6 \\
\hline \multirow[t]{4}{*}{ E3 } & Ammonia & & 7.3 & 3.6 & 41.8 & 29.1 & $12.7^{*}$ & 5.5 \\
\hline & hypoxia & & 7.1 & 7.1 & $64.3^{*}$ & 19.6 & 0.0 & 1.8 \\
\hline & Ammonia & + & 11.9 & 3.4 & 47.5 & 23.7 & 0.0 & 5.1 \\
\hline & Hypoxia & & & & & & & \\
\hline
\end{tabular}

* significantly different from the Control $\left(\mathrm{Chi}^{2}, \mathrm{p}<0.05\right)$ for each experiment 
Table 6: Significant results ( $\mathrm{p}$ values) of the three-way (treatment $\mathrm{x}$ molt stage $\mathrm{x}$ experiment) ANOVA carried out on physiological data. Only first-order interactions are taken into account.

\begin{tabular}{cccccc}
\hline Treatment & Molt stage & Experimen & Treatment & Treatment & Molt stage \\
& & $\mathrm{t}$ & $\mathrm{x}$ Molt stage & x Experiment & x Experiment
\end{tabular}

Osmoregulatory

capacity

$$
\mathrm{Mg}^{2+}
$$$$
\mathrm{Ca}^{2+}
$$

Glucose*

Lactate*

Total Proteins

Oxyhaemocyanin

THC

$<0.0001$

$<0.0001$

$$
<0.0001
$$$$
<0.0001
$$

$<0.0001$

0.0002

$<0.0001$

$<0.0001$

0.0460

$<0.0001$

0.0275

0.0032
$<0.0001$

$<0.0001$

$<0.0001<0.0001$

$<0.0001 \quad 0.0090$

0.0002

$<0.0001$

$<0.0001$

* Only Control, Ammonia and A+02 treatments were analysed 


\section{Figures}

Fig. 1: Mean $\left( \pm\right.$ SE) osmoregulatory capacity $(\mathrm{OC})(\mathrm{A}), \mathrm{Mg}^{2+}(\mathrm{B}), \mathrm{Ca}^{2+}(\mathrm{C})$, glucose $(\mathrm{D})$, lactate $(E)$, total proteins $(F)$, oxyhaemocyanin $(G)$ concentration and total haemocyte count $(H)$ in the haemolymph of juvenile $\mathrm{L}$. stylirostris in molt stages $\mathrm{C}$ and $\mathrm{D}_{2}$ in relation to different treatments: Control; Ammonia (2.39 $\left.\pm 0.08 \mathrm{mg} . \mathrm{I}^{-1} \mathrm{NH}_{3}-\mathrm{N}\right)$; Hypoxia $\left(1.37 \pm 0.06 \mathrm{mg} \mathrm{O}_{2} \mathrm{l}^{-1}\right.$ ) or Ammonia (1.59 $\left.\pm 0.31 \mathrm{mg} . \mathrm{I}^{-1} \mathrm{NH}_{3}-\mathrm{N}\right)$ combined to Hypoxia $\left(1.63 \pm 0.25 \mathrm{mg} \mathrm{O}_{2} \mathrm{I}^{-1}\right)\left(\mathrm{A}+\mathrm{O}_{2}\right)$. Mean values from 1730 determinations for stage $C$ and 17-33 determinations for stage $D_{2}$ for each treatment. Letters refer to global means for both molt stages. Treatments with different letters are significantly different $(p<0.05)$. Hypoxia treatment was not included in the analysis for glucose and lactate. A significant effect of molt stage is observed for all parameters measured.
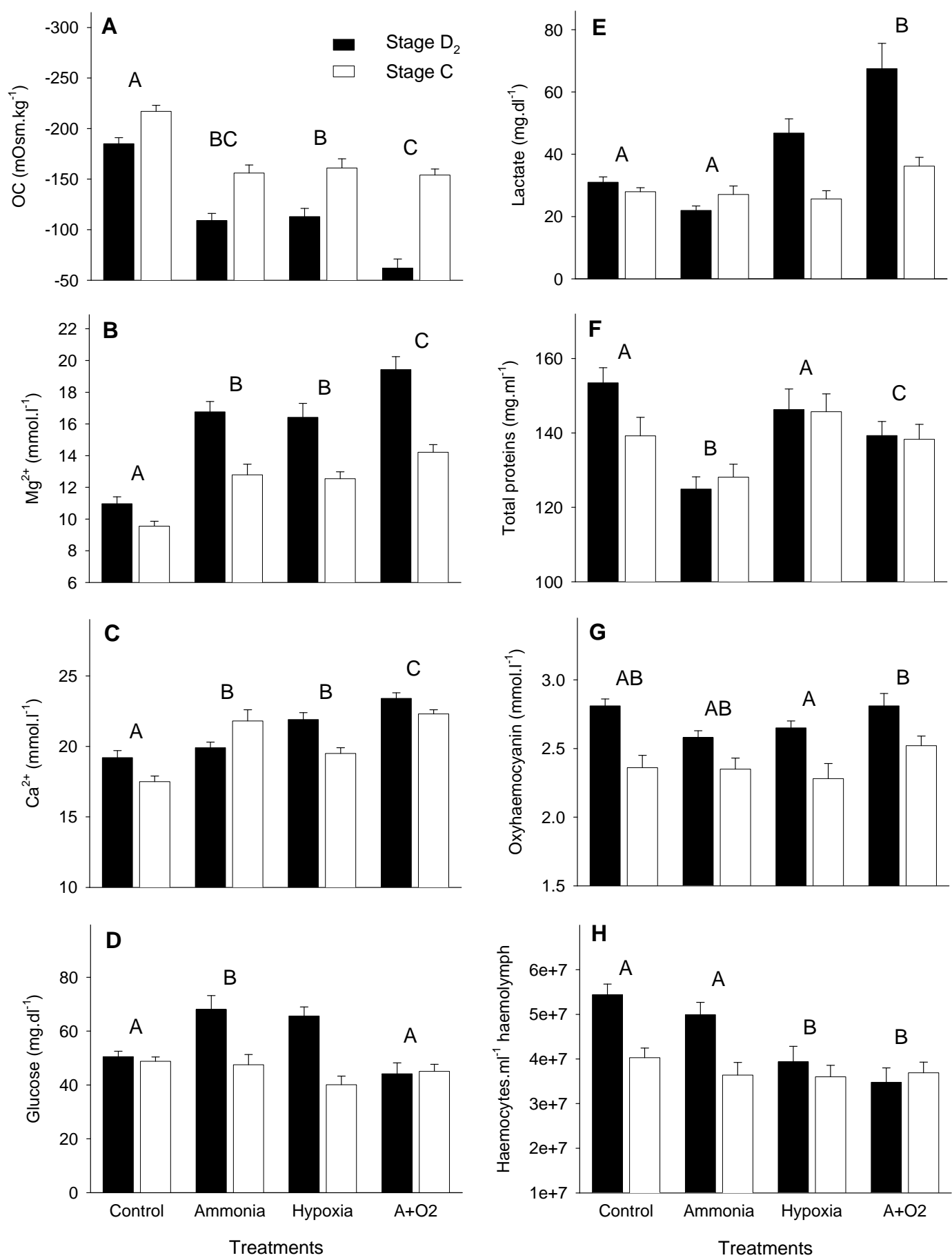